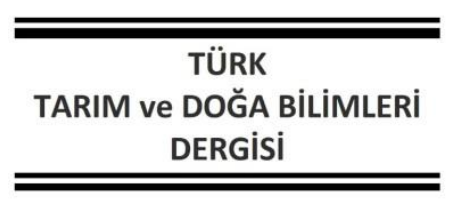

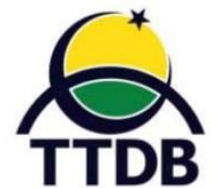

www.dergipark.gov.tr/turkjans Araştırma Makalesi

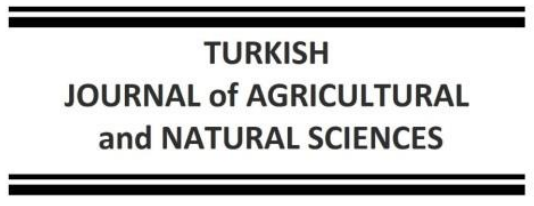

\title{
Bingöl ve Diyarbakır illerinde Yayılış Gösteren Bazı Dalgıç Böcek (Coleoptera: Dytiscidae) Türlerinin Mitokondrial Sitokrom Oksidaz Alt Ünite 1 Geni (COI) ile Filogenetik Analizi
}

\author{
Ramazan UZEN ${ }^{1}$, Kemal GÜVEN² ${ }^{2}$ Medeni AYKUT ${ }^{3 *}$, Ibrahim Halil YILDIRIM ${ }^{4}$, Fatma MATPAN BEKLER ${ }^{2}$ \\ ${ }^{1}$ Dicle Üniversitesi Fen Bilimleri Enstitüsü, 21280, Sur, Diyarbakır \\ ${ }^{2}$ Dicle Üniversitesi Fen Fakültesi, Moleküler Biyoloji ve Genetik Bölümü, 21280, Sur, Diyarbakır \\ ${ }^{3}$ Dicle Üniversitesi, Ziya Gökalp Eğitim Fakültesi, Matematik ve Fen Bilimleri Eğitimi Bölümü, 21280, Sur, \\ Diyarbakır \\ ${ }^{4}$ Dicle Üniversitesi, Veteriner Fakültesi, Genetik Bölümü, 21280, Sur, Diyarbakır
}

Geliş Tarihi: 01.03.2021 Düzeltme Geliş Tarihi: 24.03.2021 Kabul Tarihi: 14.04.2021

\section{Öz}

Dytiscidae Leach, 1815 familyası sucul böceklerin önemli bileşenlerindendir. Familya üyeleri yırtıcı dalış böcekleri olarak bilinirler ve genellikle tüm sucul habitatlara uyum göstermişlerdir. Bu çalışmada, Bingöl ve Diyarbakır illerinden Eylül 2016 ile Mayıs 2017 dönemlerinde toplanan Dytiscidae familyasının 7 cinsine ait 17 türün PCR yöntemiyle mitokondriyal DNA örnekleri elde edilerek moleküler düzeyde araştırılmıştır. Bu türlerin mitokondriyal COI genlerinin nükleotid sekansları ve PCR genomik dizileri moleküler belirteç olarak kullanıldı. Mitokondriyal DNA dizi analizleri BLAST taraması yoluyla yapıldı. 17 türe ait mitokondriyal COI gen dizileri, türlerin tanımlamasında kullanılan CLC Sequence Viewer 8. programı yardımı ile filogenetik soy ağacı oluşturularak benzerlikleri karşılaştırıldı. Türlerin yakınlık dereceleri, Neighbour Joining (NJ) soy ağacı kullanılarak belirlenmeye çalışıldı. Analiz sonuçlarına göre; Agabus faldermanni (Zaitzev, 1927) sisteme kayıtlı nükleotid dizileriyle \%100 örtüşürken, bu değer; Hydroporus planus (Fabricius, 1782)'ta \%99.88, Agabus biguttatus (Olivier, 1795) ve Laccophilus minutus (Linnaeus, 1758)'ta \%99.86, Agabus glacialis Hochhuth, 1846 'da \%99.74, Laccophilus poecilus Klug, 1834'te \%99.46, Agabus bipustulatus (Linnaeus, 1767)'ta \%99.45, Agabus nebulosus (Forster, 1771)'ta \%99.21, Hydroporus discretus Fairmaire \& Brisout, 1859 ve Ilybius chalconatus (Panzer, 1796)'ta \%99.18, Agabus conspersus (Marsham, 1802)'ta \%99.02, Bidessus calabricus Guignot, 1957'ta \%98.94, Nebrioporus stearinus suavis (Sharp, 1882)'te \%98.79, Hydroporus tessellatus (Drapiez, 1819)'ta \%97.45, Liopterus haemorrhoidalis (Fabricius, 1787)'te \%97.23, Hydroglyphus geminus (Fabricius, 1792)'te \%96.47 ve Hydroporus palustris (Linnaeus, 1761)'te \%93.54 oranlarında benzerlikler belirlenmiştir.

Anahtar kelimeler: Bingöl, Diyarbakır, Dytiscidae, COI, Moleküler tanımlama

\section{Phylogenetic Analysis of Some Diving Beetles (Coleoptera: Dytiscidae) Species with Mitochondrial Cytochrome Oxidase Subunit $1 \mathrm{Gene}$ (COI) in Bingöl and Diyarbakır Provinces}

\begin{abstract}
The family Dytiscidae Leach, 1815 is important component of aquatic beetles. The members of this family known as predaceous diving beetles and could be found in all type of fresh water habitats. In this study, 17 species belong to 7 genera of family Dytiscidae were collected from Bingöl and Diyarbakır provinces between September 2016 and May 2017. Mitochondrial DNA from these species were extracted and amplified by using PCR method. The nucleotide sequences of the mitochondrial COI genes of these species were analyzed and the PCR genomic sequences of the COI gene were used as molecular markers. Mitochondrial DNA sequence analysis was carried out by BLAST screening. 17 Mitochondrial COI gene sequences of these species were compared and phylogenetic tree was built by using CLC Sequence Viewer 8. programme, used for the species identification. DNA sequences were analyzed by using Neighbor-joining (NJ) method. The nucleotide sequence
\end{abstract}


analysis showed that the similarity of specimens collected from various locations in Bingöl and Diyarbakir provinces with the loaded nucleotide sequences were as below; 100\% in Agabus faldermanni (Zaitzev, 1927), 99.88\% in Hydroporus planus (Fabricius, 1782), 99.86\% in Agabus biguttatus (Olivier, 1795) and Laccophilus minutus (Linnaeus, 1758), 99.74\% in Agabus glacialis Hochhuth, 1846, \%99.74, Laccophilus poecilus Klug, 1834, \%99.45 in Agabus bipustulatus (Linnaeus, 1767), 99.21\% in Agabus nebulosus (Forster, 1771), 99.18\% in Hydroporus discretus Fairmaire \& Brisout, 1859 and Ilybius chalconatus (Panzer, 1796), 99.02 in Agabus conspersus (Marsham, 1802), 98.94\% in Bidessus calabricus Guignot, 1957, 98.79\% in Nebrioporus stearinus suavis (Sharp, 1882), 97.45\% in Hydroporus tessellatus (Drapiez, 1819), 97.23\% in Liopterus haemorrhoidalis (Fabricius, 1787), $96.47 \%$ in Hydroglyphus geminus (Fabricius, 1792) and $93.54 \%$ in Hydroporus palustris (Linnaeus, 1761).

Key words: Bingöl, Diyarbakır, Dytiscidae, COI, Molecular identification.

\section{Giriş}

Yırtıcı dalgıç böcekleri olarak bilinen Dytiscidae Leach, 1815 familyası yeryüzünde 182 cinse ait yaklaşık olarak 4600 tür ile temsil edilmektedir (Nilsson ve Hájek, 2021a). Bu sayı ülkemizin de içinde bulunduğu Palearktik bölgede 80 cins ve yaklaşık olarak 620 türdür (Nilsson ve Hájek, 2021b). Ülkemizde ise bugüne kadar 28 cinse ait 156 tür tespit edilmiştir (Darılmaz ve Kıyak, 2009; Fery ve Erman, 2009; Fery, 2009; Fery ve Hendrich, 2011a, b; Fery ve Przewozny, 2011; Hájek vd., 2011; Hernando vd., 2012; Vorst ve Fery, 2014; Aykut ve Fery, 2017; Aykut ve Taşar, 2018; Aykut vd., 2018; Aykut, 2018; Erman vd., 2018; Aykut vd. 2019). Bu familyaya ait türlerin boyları $1,5 \mathrm{~mm}$ ile $40 \mathrm{~mm}$ arasında değişir. Yassılaşmış ve akıntıya uyum gösteren elverişli vücutları nedeniyle iyi yüzücüdürler. Genellikle bütün sucul habitatlara uyum göstermişlerdir (Erman ve Fery 2000, 2006; Erman ve Erman 2002).

Sucul kınkanatlılar ile ilgili daha önce yapılan moleküler düzeydeki çalışmalarda; Ribera ve ark. (2003), nested clade analizi yöntemi kullanarak üç türün 22 farklı popülâsyonundan 51 bireydeki $16 \mathrm{~S}$ ribosomal RNA ve sitokrom-oksidaz 1 genlerini içeren mitokondriyal DNA sekansları kullanılarak incelediler. Çalışmada kullanılan türlerin farklı yerlerden alınarak akrabalık ilişkilerinin olduğunu ve cins türleri içerisinde görünür şekilde moleküler seviyede benzerlikler olduğunu açığa çıkardılar. Ribera ve ark. (2004) yapmış oldukları çalışmada, Agabinae'nın filogenisini belirlemek amaciyla 16S rRNA ve sitokrom oksidaz 1 (COI) mitokondriyal genlerini kullandılar. Çalışmalarında; cinsler arasındaki ilişkiler zayıf bir şekilde tanımlanmış olmasına rağmen her birinde akrabalık ilişkileri genelde sağlam ve tutarlı olup önceki morfolojik analizlerle uyumlu olduğunu saptamışlardır. Miller ve ark. (2005) yapmış oldukları çalışmada, Namibia'da toplatılan Laccophilinae'nın alt familyasına ait morfolojik olarak teşhis edemedikleri larva örneklerini sitokrom oksidaz I genin 806 bp'lik DNA dizi verilerini kullanıp, filogenetik olarak teşhis etmişlerdir. Balke ve ark. (2007); Avustralya bölgesi boyunca yaşayan sucul hayata adapte olan çeşitli Papuadytes dalgıç böceklerinin (Coleoptera: Dytiscidae) filogenisini; $\mathrm{rrnL}, \mathrm{COI}, \mathrm{cob}, \mathrm{H} 3$ ve $18 \mathrm{~S}$ rRNA gen bölgelerinden faydalanarak oluşturmuşlardır. Çalışmalarında 2808 baz çiftine sahip DNA molekülleri kullanılmıştır. Inoda ve Balke (2012), Japonya'da toplanan Dytiscus cinsine ait üç tür (Dytiscus dauricus, Dytiscus marginalis czerskii ve Dytiscus sharpi) arasındaki genetik farklılaşmayı araştırmak için mitokondrial sitokrom oksidaz altbirim 1 (COI) geninin 628 baz çiftlik dizi analizini yapmışlardır. Çalışmada ayrıca, farklı kentlerden toplanan Dytiscus sharpi türünün morfolojik olarak yüksek bir benzerlik göstermesine karşın, 20 COI baz çiftinin \%3,18 oranında farklılık gösterdiğini tespit etmişlerdir. Hernando ve ark. (2012), ülkemizde Bolu ilinde (Coleoptera: Dytiscidae: Hydroporinae) Hydroporus memnonius ve Hydroporus longulus gruplarının moleküler filogeni analizini mtDNA'nın dört gen bölgesini (COI, rrnL, trnL ve nad1) kullanarak yapmışlardır. Sekans sonuçlarını gen banktaki referans dizilerle değerlendirerek maximum likelihood ve bayesian analiz yöntemiyle sonuçları değerlendirdiler. Miller ve ark. (2013), Hydroporinae'ye ait 49 türün filogenetik yapısını moleküler ve morfolojik özelliklerden yola çıkarak oluşturmuşlardır. Analiz edilen veriler yetişkin morfolojisinin yedi gen bölgesinden (12S rRNA, 16S rRNA, sitokrom C oksidaz I, sitokrom C oksidaz II, histon III, uzama faktörü l $\alpha$ ve wnt sinyal yolağı) alınan diziler olup filogenetik ilişkilerini ortaya çıkardılar. Elde edilen veriler Maximum Likelihood (ML), Maximum Parsimony (MP), Neighbour joining (NJ) ve Bayesian analiz yöntemleri kullanılarak moleküler seviyede akrabalık ilişkileri ortaya çıkarıldı. Trizzino ve ark. (2013), Hydraena'nın 212 türü ve birkaç alttürü içeren çalışmasında iki nükleer DNA'dan alınan $4 \mathrm{~kb}$ sekans verisini ve 4 mitokondriyal gen bölgesinin (COI, rrnL, trnL ve nad1) maximum likelihood ve Bayesian metotlarını kullanarak filogenisini çıkardılar. Ertorun ve ark. (2014), ülkemizde yapmış oldukları çalışmada; Gediz nehri havzasından topladıkları 8 farklı Hydraenidae 
(Insecta: Coleoptera) türünün DNA'larını izole ederek moleküler ve morfolojik analizlerini yapmışlardır. Yeşiloğlu (2014) Hatay yöresindeki farklı bitki örtüsüne sahip, farklı yüksekliklerde bulunan 17 Ochthebius türün (Hydraenidae; Coleoptera) COI genini kullanarak, farklı moleküler çalışmalarla kıyaslamayı baz alacak şekilde tür teşhislerini yapmıştır.

Gustafson ve Miller (2017), Dineutini (Coleoptera: Gyrinidae: Gyrininae) soylarına ait 56 türün, mitokondrial gen fragmentlerinden $\mathrm{COI}$, COII, 12S; nükleer gen fragmentlerinden $\mathrm{H} 3$ ve arjinin kinaz mitokondriyal DNA sekans verilerini çıkararak ve morfolojik karakterlerini de kullanarak tür teşhislerini yapmışlardır. Çalışmalarında türlerin akrabalık ilişkileri için Bayesian ve Maximum Likelihood analizlerini kullandılar.

Ülkemizde Dytiscidae familyası ile ilgili hatırı sayılır çalışmalar yapılmıştır. Ancak yapılan çalışmalar incelendiğinde ekseri çoğunluğunun klasik morfolojik tanımlamalar ile yapıldığı görülmektedir. Son yıllarda klasik yöntemler ile tür teşhislerinin yapılması yeterli görülmemektedir. Moleküler düzeyde tür teşhisleri gereklilik arz etmektedir. Bu çalışmamızda Bingöl ve Diyarbakır illerinin Dytiscidae familyasına ait bazı türlerin tanımlanması için mitokondriyal DNA'nın sitokrom oksidaz alt ünite 1 (COI) gen bölgesi kullanılarak dizi analizi yöntemi ile biyoinformatik programlarından yararlanarak genetik yapılarının incelenmesi ve moleküler düzeyde türlerin sistematiklerinin ortaya çıkarılması amaçlanmıştır. Çalışmamız bu yönü ile bölgemizde ilk olma özelliğini göstermektedir.

\section{Materyal ve Metot}

Örneklerin Toplanması: Çalışmaya konu olan Dytiscidae familyasına ait sucul böcek örnekleri Eylül 2016 ile Mayıs 2017 dönemlerinde Bingöl ve Diyarbakır illerinin, dere, göl, gölet, kaynak, göze, su birikintisi gibi çeşitli sucul ortamlardan 0,5 $\mathrm{mm}$ çapa sahip atraplar kullanılarak toplandı (Çizelge 1.). Toplanan örnekler çalışma alanında \%98'lik etil alkol çözeltisine alındı. Örnek alınan lokalitelerin koordinatları el GPS'i (Magellan Explorist 610) yardımı ile kayıt altına alındı. Laboratuar ortamına getirilen örnekler DNA izolasyon işlemleri yapılana kadar $-20{ }^{\circ} C^{\prime}$ de bekletildi.

PCR Aşaması: DNA izolasyonu için Qiagen (QIAquick PCR pürifikasyon kiti, Hilden, Almanya) kiti standart protokolü ile kullanıldı. İzole edilen DNA'lar PCR (Polimerase Chain Reaktion
=Polimeraz Zincir Reaksiyonu) yöntemi ile çoğaltıldı. PCR karışımı için evrensel primerler (ileri 5'- CAA CAT TTA TTT TGA TTT TTT GG -3' ve geri 5'TCC AAT GCA CTA ATC TGC CAT ATT A A-3' ) kullanılmıştır. PCR yöntemi ile çoğaltılıp izole edilen mtDNA örneklerinin doğrulanması amacıyla Agaroz Jel Elektroforezine yüklenip yeterli süre yürütülmüştür. İzolasyon sonucu yeterli süre yürütülen örnekler jel görüntüleme cihazına alınarak U.V. ışık altında görüntülendi. EtBr ile U.V. ışık altında görünür hale gelen bantlar amplifikasyonun doğrulanması amacıyla UV jel görüntüleme cihazında (Quantum ST4 Vilber Lourmat) fotoğraflanmıştır.

DNA Sekans Analizi: Elde edilen PCR ürünün agaroz jelde tespit edilmesinden sonra $P C R$ ürünü Genematrix stool DNA pürifikasyon kiti (EURX) ile üretici talimatlarına uygun olarak saflaştırıldı. PCR için kullanılan primerler Dytiscidae cinslerinin DNA veri bankasında mevcut mitokondriyal sitokrom oksidaz alt ünite 1 (COI) gen bölgeleri kullanılmıştır. Diziler gen bank (https://www.ncbi.nlm.nih.gov/) verileri ile karşılaştırılmıştır. Bütün reaksiyonlarda Applied thermal cycler (Applied Biosystems Inc., A.B.D.) kullanılmıştır. Reaksiyon $1.5 \mathrm{mM} \mathrm{MgCl}, 0.2 \mathrm{mM}$ dNTP mix, 1x Reaksiyon Tamponu, 0.2U Taq DNA Polimeraz, $5 \mathrm{ng} / \mu \mathrm{l}$ kalıp DNA ve her bir primerden $0.5 \mu \mathrm{M}$ içermektedir. Cihazda, primer çiftine özgü optimizasyonu sağlanmıştır.

Filogenetik Analiz: DNA sekansları, CLC Sequence Viewer 8. programı kullanılarak görüntülendi ve ayrı ayrı FASTA formatında kaydedildi. Her bir böcek türü için $\mathrm{COI}$ gen bölgesine ait diziler FASTA formatında NCBI Nucleotide BLAST (Basic Local Alignment Search Tool= Basit Lokal Dizi Araştırma Aracı)'a yüklendi. NCBI veri bankasında kayıtlı dizilerle benzerlikleri karşılaştırıldı. Elde edilen türlerin sekans sonuçlarının filogenetik analizleri Neighbour Joining (NJ) ve Unweighed Pair Group Method of Aritmetic Averages (UPGMA) modeline göre CLC Sequence Viewer 8 programı ve www.itol.embl.de aracılığı ile gerçekleştirildi ve moleküler filogenetik soyağacı oluşturuldu. Soyağacı oluştururken Noteridae familyasından Noterus crassicornis (HM376195) türü dış grup olarak kullanıldı. Filogenetik ağaç oluşturulurken Bootstrap 1000 metodu kullanıldı. Elde edilen sekans sonuçları neticesinde örneklerimizin $\mathrm{COI}$ gen dizilimi ve $\mathrm{NBCl}$ kayıtlarından alınan örneklerle benzerliklerine göre yapılan dizi analiz sonuçları oluşturuldu. 
Çizelge 1. Dytiscidae familyasına ait örneklerin toplandığı lokalite bilgileri

\begin{tabular}{|c|c|c|c|}
\hline Organizma & Örneğin Toplandığı yer ve tarih & Koordinatlar & $\begin{array}{c}\text { Rakım } \\
(\mathrm{m})\end{array}$ \\
\hline Agabus biguttatus & $\begin{array}{l}\text { Bingöl- Solhan, Yüzen adalar milli parkı, } \\
\text { 19.05.2017 }\end{array}$ & $38017^{\prime} 16^{\prime \prime} \mathrm{N} 40034^{\prime} 44^{\prime \prime} \mathrm{E}$ & 1331 \\
\hline Agabus bipustulatus & Bingöl, Gümülü köyü, 19.09.2016 & $38^{\circ} 43^{\prime} 18^{\prime \prime} \mathrm{N} 40^{\circ} 48^{\prime} 57^{\prime \prime} \mathrm{E}$ & 1087 \\
\hline Agabus conspersus & Binböl, Genç, Doğanca köyü, 18.09.2016 & $38^{0} 59^{\prime} 53^{\prime \prime} \mathrm{N} 40^{0} 55^{\prime} 35^{\prime \prime} \mathrm{E}$ & 1267 \\
\hline Agabus faldermanni & Bingöl, Adaklı, Akbinek köyü, 21.09.2016 & $39^{0} 24^{\prime} 45^{\prime \prime} \mathrm{N} 40^{\circ} 43^{\prime} 10^{\prime \prime} \mathrm{E}$ & 1496 \\
\hline Agabus glacialis & Bingöl, Yedisu, 18.05.2017 & $39^{\circ} 44^{\prime} 07^{\prime \prime} \mathrm{N} 40^{0} 53^{\prime} 55^{\prime \prime} \mathrm{E}$ & 1479 \\
\hline Agabus nebulosus & Diyarbakır, Kocaköy, Gökçe köyü, 24.09.2016 & $38033^{\prime} 37^{\prime \prime} \mathrm{N} 40052^{\prime} 56^{\prime \prime} \mathrm{E}$ & 1175 \\
\hline Bidessus calabricus & Diyarbakır, Eğil, 25.09.2016 & $38024^{\prime} 37^{\prime \prime} \mathrm{N} 40008^{\prime} 53^{\prime \prime} \mathrm{E}$ & 1205 \\
\hline Hydroglyphus geminus & Diyarbakır, Hantepe köyü, 26.09.2016 & $38010^{\prime} 23^{\prime \prime} \mathrm{N} 40017^{\prime} 29^{\prime \prime} \mathrm{E}$ & 923 \\
\hline Hydroporus discretus & Diyarbakır, Tokaçlı köyü, 28.09.2016 & $37054^{\prime} 27^{\prime \prime} \mathrm{N} 39055^{\prime} 59^{\prime \prime} \mathrm{E}$ & 846 \\
\hline Hydroporus palustris & Diyarbakır, Karacadağ dağları - L2, 29.09.2016 & $37046^{\prime} 21^{\prime \prime} \mathrm{N} 39049^{\prime} 06^{\prime \prime} \mathrm{E}$ & 1616 \\
\hline Hydroporus planus & Diyarbakır, Çüngüş, yeniköy köyü, 24.04.2017 & $38011^{\prime} 08^{\prime \prime} \mathrm{N} 39024^{\prime} 55^{\prime \prime} \mathrm{E}$ & 881 \\
\hline Hydroporus tesellatus & Diyarbakır, Çınar, Göksu köyü, 28.04.2017 & $37041^{\prime} 47^{\prime \prime} \mathrm{N} 40026^{\prime} 51^{\prime \prime} \mathrm{E}$ & 670 \\
\hline Ilybius chalconatus & Diyarbakır, Kulp, Savaş köyü, 30.04.2017 & $38024^{\prime} 44^{\prime \prime} \mathrm{N} 41002^{\prime} 13^{\prime \prime} \mathrm{E}$ & 750 \\
\hline Laccophilus minutus & Diyarbakır, Kulp, Yücebağ köyü, 30.04.2017 & $38022^{\prime} 05^{\prime \prime} \mathrm{N} 41028^{\prime} 46^{\prime \prime} \mathrm{E}$ & 735 \\
\hline Laccophilus poecilus & Bingöl, Karlıova, Çatak köyü, 17.05.2017 & $39^{0} 38^{\prime} 42^{\prime \prime} \mathrm{N} 41^{0} 03^{\prime} 12^{\prime \prime} \mathrm{E}$ & 1837 \\
\hline Liopterus haemorrhoidalis & Bingöl, Adaklı, Sütlüce köyü, 22.09.2016 & $39^{0} 11^{\prime} 20^{\prime \prime} \mathrm{N} 40^{\circ} 66^{\prime} 15^{\prime \prime} \mathrm{E}$ & 1725 \\
\hline Nebrioporus stearinus suavis & Bingöl, Yamaç beldesi, 19.09.2016 & $38^{\circ} 27^{\prime} 32^{\prime \prime} \mathrm{N} 40^{\circ} 44^{\prime} 31^{\prime \prime} \mathrm{E}$ & 1375 \\
\hline
\end{tabular}

\section{Bulgular ve Tartışma}

Çalışmamızda Dytiscidae familyasının 7 cinsine ait toplam 17 taksonun mitokondriyal DNA örnekleri PCR yöntemiyle çoğaltıldı ve COI geni çalışılmıştır. PCR sonuçlarında örneklerimizin bant uzunluğu yaklaşık olarak 850 baz çiftine tekabül etmektedir (Şekil 1).

Örneklerimizin DNA sekans dizileri GenBank'a yüklenerek, her örnek için Accession (erişim) numaraları alındı. Örneklerimiz için alınan erişim numaraları, benzerlik oranları, lokalite bilgileri Çizelge 1 ve 2' de verilmiştir. Çalışmamızda her bir örneğe ait COI DNA dizileri ayrı ayrı NCBI Blast'a girilerek veri tabanında kayıtlı böcek türleriyle benzerlik oranları karşılaştırıldı. Analiz sonuçlarına göre; Agabus faldermanni (Zaitzev, 1927) sisteme kayıtlı nükleotid dizileriyle \%100 örtüşürken, bu değer; Hydroporus planus (Fabricius, 1782)'ta \%99.88, Agabus biguttatus
(Olivier, 1795) ve Laccophilus minutus (Linnaeus, 1758)'ta \%99.86, Agabus glacialis Hochhuth, 1846 'da \%99.74, Laccophilus poecilus Klug, 1834'te \%99.46, Agabus bipustulatus (Linnaeus, 1767)'ta \%99.45, Agabus nebulosus (Forster, 1771)'ta \%99.21, Hydroporus discretus Fairmaire \& Brisout, 1859 ve Ilybius chalconatus (Panzer, 1796)' ta \%99.18, Agabus conspersus (Marsham, 1802)'ta \%99.02, Bidessus calabricus Guignot, 1957'ta \%98.94, Nebrioporus stearinus suavis (Sharp, 1882)' te \%98.79, Hydroporus tessellatus (Drapiez, 1819)'ta \%97.45, Liopterus haemorrhoidalis (Fabricius, 1787)'te \%97.23, Hydroglyphus geminus (Fabricius, 1792)'te \%96.47 ve Hydroporus palustris (Linnaeus, 1761)'te \%93.54 oranlarında benzerlikler belirlenmiştir (Çizelge 2). Ayrıca örneklerimizden elde edilen DNA sekans dizilerine göre moleküler filogenetik soyağacı oluşturuldu (Şekil 2). 


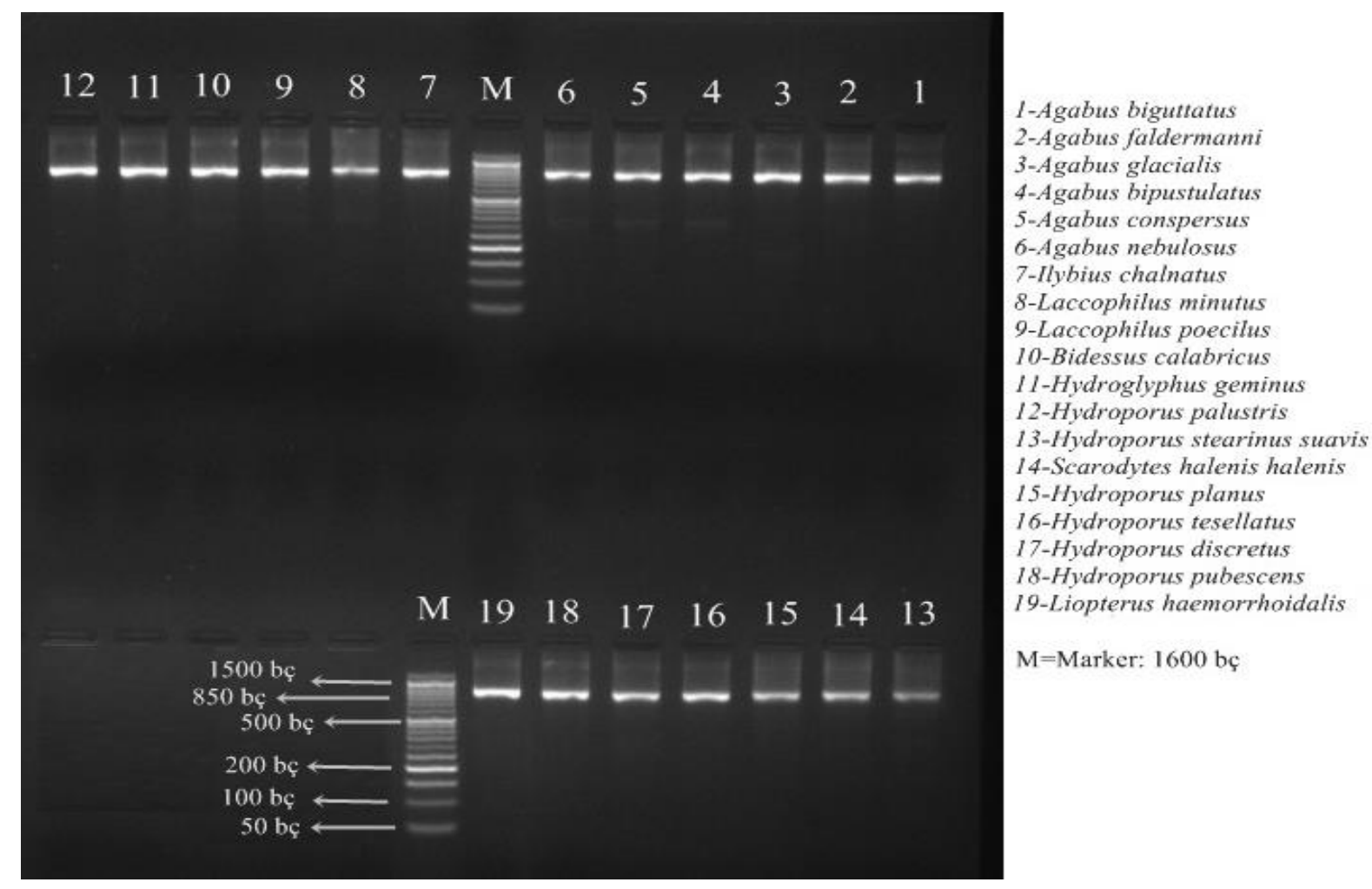

Şekil 1. Çalışma bölgemizde belirlenen türlere ait PCR sonuçları.

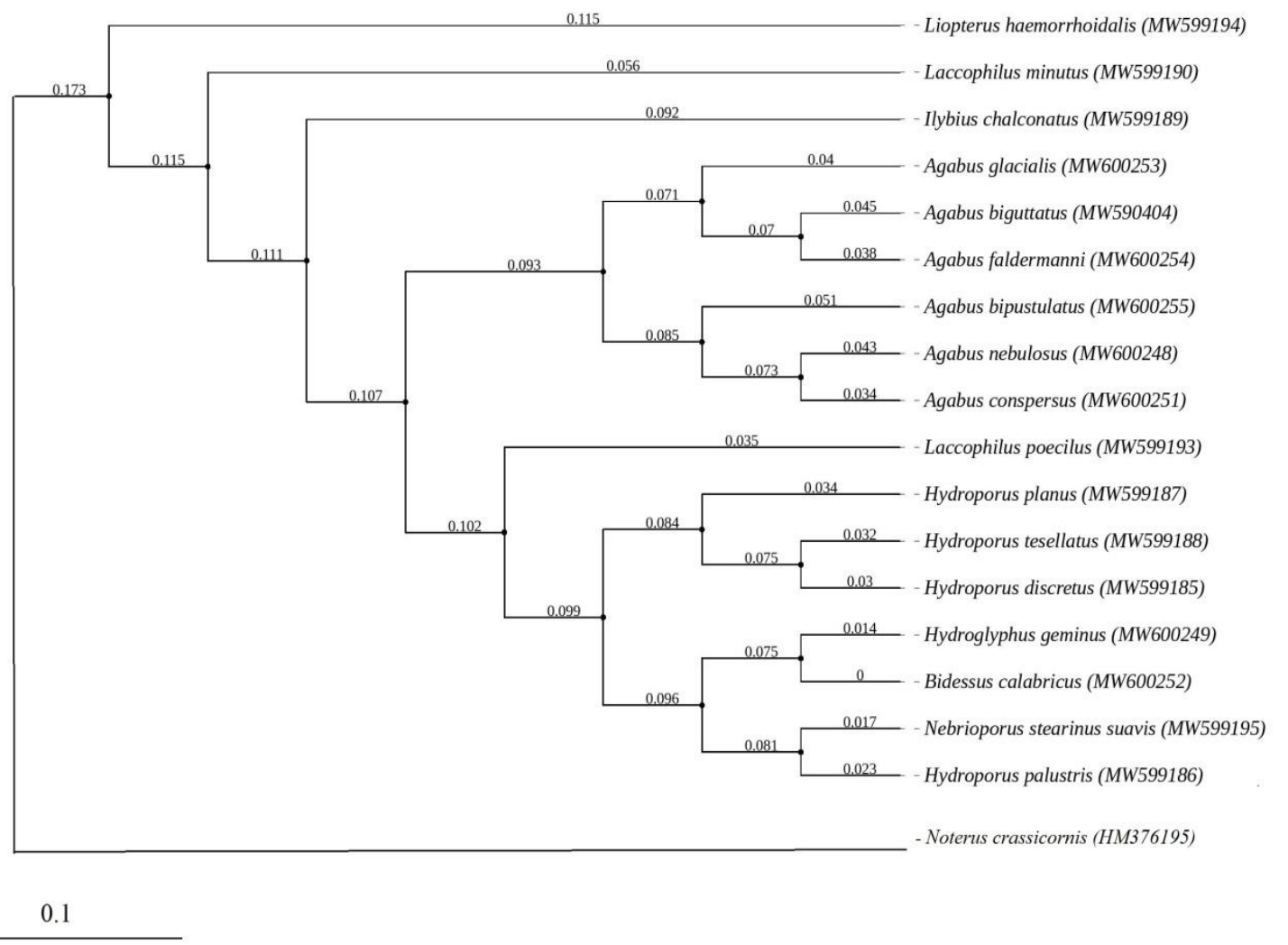

Şekil 2. Çalışma bölgemizde belirlenen türlere ait Neighbour Joining (NJ) ağacı 
Çizelge 2. Dytiscidae familyasına ait örneklerin Gen Bank erişim numaraları ve nükleotid benzerlik oranları.

\begin{tabular}{|c|c|c|c|}
\hline Organizma & $\begin{array}{c}\text { Gen Bank } \\
\text { erişim } \\
\text { numarası }\end{array}$ & $\begin{array}{l}\text { Benzerlik } \\
\text { Oranı (\%) }\end{array}$ & $\begin{array}{l}\text { Nükleotid karşılaştırılması yapılan } \\
\text { organizma ve erişim numarası }\end{array}$ \\
\hline Agabus conspersus & MW600251 & 99.02 & Agabus conspersus (JQ355171.1) \\
\hline Agabus nebulosus & MW600248 & 99.21 & Agabus nebulosus (AY138714.1) \\
\hline Agabus bipustulatus & MW600255 & 99.45 & Agabus bipustulatus (JQ355220.1) \\
\hline Agabus faldermanni & MW600254 & 100.0 & Agabus faldermanni (LM654880.1) \\
\hline Agabus glacialis & MW600253 & 99.74 & Agabus glacialis (LM654902.1) \\
\hline Laccophilus poecilus & MW599193 & 99.46 & Laccophilus poecilus (AY334246.1) \\
\hline Hydroporus discretus & MW599185 & 99.18 & Hydroporus discretus (HE610202.1) \\
\hline Hydroporus tesellatus & MW599188 & 97.45 & Hydroporus tesellatus (LT882817.1) \\
\hline Hydroporus planus & MW599187 & 99.88 & Hydroporus planus (HE610215.1) \\
\hline Hydroporus palustris & MW599186 & 93.54 & Hydroporus palustris (HQ165020.1) \\
\hline Nebrioporus stearinus suavis & MW599195 & 98.79 & Nebrioporus stearinus suavis (HF931154.1) \\
\hline Laccophilus minutus & MW599190 & 99.86 & Laccophilus minutus (JN843524.1) \\
\hline Ilybius chalconatus & MW599189 & 99.18 & Ilybius chalconatus (JQ356195.1) \\
\hline Bidessus calabricus & MW600252 & 98.94 & Bidessus calabricus (AJ850572.1) \\
\hline Hydroglyphus geminus & MW600249 & 96.47 & Hydroglyphus geminus (AM947831.1) \\
\hline Liopterus haemorrhoidalis & MW599194 & 97.23 & Liopterus haemorrhoidalis ( KT876902.1) \\
\hline Agabus biguttatus & MW590404 & 99.86 & Agabus biguttatus (JQ356189.1) \\
\hline
\end{tabular}

\section{Sonuç ve Öneriler}

Sonuç olarak; çalışmamızda; örneklerimizin yaklaşık olarak 700-850 baz çiftine tekabül eden COI geni çalışılmıştır. Daha önce yapılan çalışmaların ekseri çoğunluğunda COI geni çalışılması ve bu çalışmalarda 600-806 arasında değişen baz çiftinin çalışılması (Balke ve ark. (2007) 2808 bp çalışmışlardır) değerlendirildiğinde, çalışmamızın bu yönü ile daha önce yapılan ve giriş bölümünde sıralanan çalışmaların birçoğu ile örtüştüğü görülmektedir. Çalışmamızda örneklerimizin NCBI'da kayıtlı örneklerle kıyaslandığında yüksek oranda benzerlik olduğu görülmektedir. Ancak Hydroporus palustris (Linnaeus, 1761)' te nispeten düşük bir benzerlik oranı elde edilmiştir. Inoda ve Balke (2012) tarafından yapılan bir çalışmada farklı kentlerden toplanan aynı türde 20 COI baz çiftinin \%3,18 oranında farklılık gösterdiğini tespit etmişlerdir. Bu bulgu $H$. Palustris için elde ettiğimiz $\% 6,46^{\prime} l \mathrm{k}$ farklılığın kabul edilebilir bir farklılık olduğunu göstermektedir. Dytiscidae familyasına ait katalogta (Nilsson ve Hájek, 2021a) Hydroporus Clairville, 1806 cinsine ait fuscipennis grubuna dahil edilen; Hydroporus planus, $H$. discretus ve
H.pubescens'in filogenetik ağaçta aynı dalda olması ve kuvvetli bir bağa sahip olması çalışmamızda elde ettiğimiz verileri doğrular niteliktedir. Aynı şekilde Agabus (Leach, 1817) cinsine ait altı türümüzün filogenetik ağaçta aynı dalda olması ve Gaurodytes (Thomson, 1859) alt cinsi, guttatus grubuna dahil edilen Agabus biguttatus, $A$. faldermanni ve $A$. glacialis'in soy ağacımızda en güçlü bağa sahip türler olarak görülmesi de çalışmamızda elde ettiğimiz moleküler verilerin katalog (Nilsson ve Hájek, 2021a) verileri ile örtüştüğünü göstermektedir. Sonuç olarak yaşa, cinsiyete, çeşitli yaşam koşullarına bağlı olarak organizmaların klasik morfolojik benzerliklerinin bulunduğu tanımlamanın yetersiz kaldığı durumlarda tür teşhisinin doğruluğunu ve güvenirliliğini tespit etmek için moleküler tanımlamanın özellikle Dytiscidae gibi kalabalık familyalar için vazgeçilmez olduğu görülmektedir.

Teşekkür: Bu çalışma Dicle Üniversitesi Bilimsel Araştırma Projeleri (DÜBAP) Koordinatörlüğü FEN.17.007 nolu proje ile desteklenmiştir. Destekleri için DÜBAP Koordinatörlüğüne teşekkür 
ederiz. Bu çalışma Prof. Dr. Kemal GÜVEN ve Doç. Dr. Medeni AYKUT ortak danışmanlığında yürütülen Ramazan UZEN'in Yüksek Lisans tezinden üretilmiştir.

Çıkar Çatışması Beyanı: Makale yazarları aralarında herhangi bir çıkar çatışması olmadığını beyan ederler.

Araştırmacıların Katkı Oranı Beyan Özeti: Yazarlar makaleye eşit oranda katkı sağlamış olduklarını beyan ederler.

\section{Kaynaklar}

Aykut, M. ve Fery, H. 2017. Scarodytes costatus nov. sp. from the Bingöl Province in Turkey, the first species of the genus with costate elytra (Insecta: Coleoptera: Dytiscidae: Deronectina). Linzer biologische Beiträge, 49: 395-414.

Aykut, M. ve Taşar, G.E. 2018. Contributions to the knowledge of Adephagan fauna in Adıyaman Province, Turkey (Coleoptera: Dytiscidae, Gyrinidae, Haliplidae and Noteridae). Munis Entomology\&Zoology, 13: 249-255.

Aykut, M., Taşar, G.E. ve Fery, H. 2018. Deronectes taron sp.n. from the eastern Anatolian region of Turkey (Coleoptera, Dytriscidae, Hydroporinae). Zootaxa, 4422 (2): 403-410.

Aykut, M. 2018. The Diving Beetle Fauna of Diyarbakır and Bingöl Provinces, Turkey (Coleoptera: Dytiscidae) with a New Record. Pakistan Journal of Zoology, 50 (1): 65-74.

Aykut, M., Yıldırım, i.H., Tusun, S. ve Fery, H. 2019. Deronectes kabilcevz sp. n. And $D$. Propedoriae sp. n. From South-eastern Anatolia (Turkey) (Coleoptera, Dytiscidae, Hydroporinae). Zootaxa, 4691 (1): 5-10.

Balke, M., Ribera, I. ve Vogler, A.P. 2004. MtDNA phylogeny and biogeography of Copelatinae, a highly diverse group of tropical diving beetles (Dytiscidae). Molecular Phylogenetics and Evolution, 32: 866-880.

Balke M., Pons J., Ribera I., Sagata K. ve Vogler A.P. 2007, Infrequent and unidirectional colonization of hyperdiverse Papuadytes diving beetles in New Caledonia and New Guinea. Molecular Phylogenetics and Evolution 42: 505-516.

Darılmaz, M.C. ve Kıyak, S. 2009. Checklist of Gyrinidae, Haliplidae, Noteridae and Dytiscidae of Turkey (Coleoptera:
Adephaga). Journal of Natural History,43: 1585-1636.

Erman, Ö.K. ve Fery, H. 2000. Hydroporus erzurumensis sp.n. (Insecta: Coleoptera: Dytiscidae) from north-eastern Turkey. Annalen des Naturhistorischen Museums in Wien, 102B:171-176.

Erman, Ö.K. ve Erman, O. 2002. First records of Oreodytes Seidlitz, 1887 (Dytiscidae, Coleoptera) from Turkey: Oreodytes septentrionalis (Gyllenhal, 1826) and Oreodytes davisii (Curtis, 1831). Türkish Journal of Zoology, 26: 295-299.

Erman, Ö.K. ve Fery, H. 2006. Hydroporus neclae sp.n. from north-eastern Turkey, a new member of the memnonius-group of Hydroporus Clairville (Coleoptera: Dytiscidae). Zootaxa, 1355: 39-47.

Erman, Ö.K., Taşar, G.E., Aykut, M. ve Kurt, K. 2018. First record of Hydaticus histrio Clarck, 1864 (Coleoptera, Dytiscidae) from Turkey. Acta Biologica Turcica, 31 (4): 174-177.

Ertorun, N. Şen, C. ve Biter, E. 2014. Bazı Hydraenidae (Insecta: Coleoptera) Türlerinin Moleküler ve Morfolojik Analizleri. 22. Ulusal Biyoloji Kongresi, 23-27 Haziran, Eskişehir, s. 1141.

Fery, H. ve Erman, O.K. 2009. Five new species of the longulus-group of Hydroporus Clairville, 1806 from north-eastern Turkey (Coleoptera: Dytiscidae). Zootaxa, 2033: 112.

Fery, H. 2009. New species of the Hydroporus longulus group from Iran, Armenia and Turkey with a synopsis of the group (Coleoptera: Dytiscidae). Acta Entomologica Musei NationalisPragae,49: 529-558.

Fery, H. ve Hendrich, L. 2011a. Hydroporus esersi sp. n., a new diving beetle from southern Turkey (Coleoptera, Dytiscidae, Hydroporinae). Zootaxa, 2909: 38-46.

Fery, H. ve Hendrich, L. 2011b. Ilybius enpalaiatheka spec. nov. from Anatolia, Turkey, with a revised key to males of the llybius erichsoni and chalconatus groups. Spixiana, 34: 39-46

Fery, H. ve Przewoźny, M. 2011. Ilybius thynias sp. n. from European Turkey (Coleoptera: Dytiscidae). Zootaxa, 2740: 59-67.

Gustafson, G.T. ve Miller, K.B. 2017. Systematics And Evolution of The Whirling Beetle Tribe Dineutini (Coleoptera: Gyrinidae: Gyrininae), Zoological Journal of the Linnean Society, XX: 1-33

Hájek, J., Štastný, J., Boukal, M. ve Fery, H. 2011. Updating the eastern Mediterranean 
Deronectes (Coleoptera: Dytiscidae) with the description of two new species from Turkey. Acta Entomologica Musei NationalisPragae, 51: 463-476.

Hernando, C., Aguilera, P., Castro, A. ve Ribera, I. 2012. A new interstitial species of the Hydroporus ferrugineus group from northwestern Turkey, with a molecular phylogeny of the $H$. Memnonius and related groups (Coleoptera: Dytiscidae: Hydroporinae). Zootaxa, 3173: 37-53.

Inoda, T. ve Balke, M. 2012. Status of Japanese Dytiscus Species (Coleoptera: Dytiscidae) Based On Mitochondrial DNA Sequence Data. Entomological Science, 15: 246-249.

Miller, K.B., Alarie, Y., William Wolfe, G. ve Whiting, M.F. 2005. Association of insect life stages using DNA sequences: the larvae of Philodytes umbrinus (Motschulsky) (Coleoptera: Dytiscidae). Systematic Entomology, 30: 499-509.

Miller, K.B. Jean, A., Alarie, Y., Hardy, N. ve Gibson, R. 2013. Phylogenetic placement of North American subterranean diving beetles (Insecta: Coleoptera: Dytiscidae). Arthropod Systematıcs \& Phylogeny, 71 (2): 75-90.

Nilsson, A.N. ve Hájek, J. 2021a. Catalogue of Palearctic Dytiscidae (Coleoptera). World Wide Web Electronic Publication, http://www. waterbeetles.eu [accessed 25 February, 2021].

Nilsson, A.N. ve Hájek, J. 2021b. A world catalogue of the family Dytiscidae (Coleoptera, Adephaga). World Wide Web Electronic Publication, www.waterbeetles.eu [accessed 25 February, 2021]

Ribera, I., Hogan, J.E. ve Vogler, A.P. 2003. Phylogeny of Hydradephagan Water Beetles Inferred from 18S rRNA Sequences. Molecular Phylogenetics and Evolution, 23 (1): 43-62.

Ribera, I., Nilson, A.N. ve Vogler A.P. 2004. Phylogeny and historical biogeography of Agabinae diving beetles (Coleoptera) inferred from mitochondrial DNA sequences. Molecular Phylogenetics and Evolution, 30: 545-562.

Ribera, I., Vogler, A.P. ve Balke, M. 2007. Phylogeny and diversification of diving beetles (Coleoptera:Dytiscidae). Cladistics, 24: 563-590.

Trizzino, M., Jach, M.A., Audisio, P., Alonso, R. ve Ribera, I. 2013. A molecular phylogeny of the cosmopolitan hyperdiverse genus Hydraena Kugelann (Coleoptera, Hydraenidae). Systematic Entomology, 38: 192-208.
Yeşiloğlu, M. 2014. Hatay Yöresindeki Ochtheirus Türlerinin (Hydraenidae; Coleoptera) Çeşitliliğinin Mitokondriyal Cox Alt Ünite 1 Geni Hedeflenerek Ortaya Çıkarılması, (Yüksek Lisans Tezi), Mustafa Kemal Üniversitesi, Hatay, s. 41. 